\title{
Media and Information Literacy: A Critical Response to the Challenge of 'Infodemic' in the Covid-19 Pandemic Era in Nigeria
}

\author{
Elizabeth Titilayo Aduloju, Ph.D \\ Department of Communication Studies, Catholic Institute of West Africa, Port Harcourt, Nigeria
}

\begin{abstract}
Nigeria, the most populous country in Africa is not left out in the fight against the COVID-19 outbreak that continues to ravage the entire universe. The deadly virus as of 26th June 2021 has infected more than $\mathbf{1 8 1 . 3}$ million people and killed over 3.9 million people globally. In Nigeria alone, it has infected over 167 thousand people and killed 2,119 people between February $27^{\text {th }}$, the day the first case was recorded and $26^{\text {th }}$ June 2021. Unfortunately, as the virus continues to spread worldwide, there is also a rapid increase in the rate of infodemic - information overload majority of which are fake, disinformation and misinformation - about the virus, its transmission and cure. Thus, this paper interrogates the present reality of the infodemic in Nigeria, especially in the present COVID-19 pandemic and the vision of media and information literacy. The problem concerned the extent to which infodemic could precariously engineer crisis, disgust, fear, hostility and panic which might degenerate to conflict, insecurity, stigmatisation and eventual death. Combining textual analysis with receptor oriented, the article critically examined the social media platform posts and activities in this domain. Major findings apart from revealing that the free and unlimited access to information on social media platforms have been the active driver of the current experience, also showed that the inability of people to discern the veracity and authenticity of information within the context of the COVID-19 pandemic have made many vulnerable. Thus, the present article concluded that media and information literacy is a necessity in fighting the challenge of infodemic in Nigeria and promoting healthy information in media and technological environments. Therefore, among others, the introduction of media and information literacy to both literate and illiterate sectors of society is recommended.
\end{abstract}

Keywords: Coronavirus/Covid-19, Infodemic, Media and Information Literacy, Misinformation, Social Media Platforms

\section{INTRODUCTION}

$\mathrm{T}$ he current digital era is a phase in human experience where a shift process occurs from industrial-based to an information-based economy using the computer or other technology devices as a medium of communication. This era according to Lau (2003) is a time in which there is widespread, ready and easy access to sharing of and use of information in an electronically accessible environment. Of course, the retrieval and transmission of information with and among people depend mainly on the Internet. Thus, the contemporary era is called the information and communication era as many studies are conducted regarding the collection, processing and transferring of information (Bahman, 1991, cited in Haris, 2016). The information has been developed rapidly around the world, that today; the world is not only suffering from coronavirus pandemic alone but also facing the challenge of information overload which has been termed infodemic. Modern devices such as smartphones, mobile computers, PDA, tablets created in this age are vital in creating and transmitting information seamlessly.

The global COVID-19 pandemic is happening at a time when sorting facts from fiction is increasingly difficult (Hassan, 2020). Ever since the advent of the coronavirus in December 2019, the entire world has been thrown into the sea of uncertainty but daily making efforts to curtail the spread of this deadly virus and seek the cure (antivirus). As the coronavirus pandemic otherwise known as COVID-19 heightens nerves and spread its tentacles across countries of the world, there is also a rapid increase in the rate of infodemic - information overload, many of which are fake, dis- and misinformation - about the virus and its transmission as being experienced and witnessed today. Hassan (2020) avers that in Nigeria, a tsunami of fake news, mis- and disinformation has accompanied the virus' spread, provoking fear and exploiting vulnerabilities. Thus, like the highly infectious and deadly COVID-19 pandemic, infodemic is also a big challenge that could be contagious and could be a matter of life and death during a pandemic situation. Although according to Suraj (2020), both Covid-19 and infodemic are non-human, they are used by human agents to render havoc to humanity. Unfortunately, these viruses (Covid-19 and infodemic) have disregarded known solutions to a certain extent. For instance, they spread via contacts and multiply in thousands. Besides, they spread amazingly fast through ignorance and thrive on fear and cause panic.

Whether out of ignorance, malice or genuine alarm, infodemics continue to circulate round the country causing more fear and devastating experiences even more than the virus itself. In today's world of new media technology proliferation, particularly social media, everyone is a producer and consumer (Prosumer) of media content (Aduloju, 2019). Of course, observations have revealed that the free and unlimited access to information on social media platforms has been the active driver of the current experience, and most 
importantly, the inability of people to discern the veracity and authenticity of information they receive within the context of COVID-19 pandemic. On this, the Director-General of World Health Organisation (WHO), Tedros Adhanom Ghebreyesus at the Munich Security Conference on Feb 15, 2020, states that WHO is leading and making all efforts to slow the spread of the coronavirus disease outbreak. But a global epidemic of misinformation -spreading rapidly through social media platforms and other outlets- poses a serious problem for public health. He avers that "We're not just fighting an epidemic; we're fighting an infodemic" (Zarocostas, 2020, n.p)

The spread of mis- and disinformation happens often in our everyday lives in Nigeria. The impact in this context is potentially more precarious as it can engineer crisis, fear and panic which may degenerate to conflict, insecurity in the nation and even death. Thus, Suraj (2020) argues that, as efforts are being made to flatten the Covid-19 rising curve, equal efforts should also be mounted to flatten the curve of disinformation, misinformation and fake news in Nigeria. Today, our common enemy is a virus, but our enemy is also a growing surge of mis- and disinformation. Accordingly, to overcome this virus, there is a need to urgently promote facts and media and information literacy. A cursory look at the current experience of infodemics in Nigeria, it has become clearer that, to successfully fight Covid-19, the first step is to wage war against disinformation, misinformation and fake news by being media and information literate.

Thus, to counter infodemic, this paper argues that being media and information literate could be a critical response in fighting the challenge of disinformation and misinformation in Nigeria and promote healthy information in media and technological environments. In other words, media and information literacy (MIL) competencies are foundational, necessary and urgent for citizens of Nigeria. Undeniably, MIL is an everyday necessity, particularly during turbulent times when disinformation, misinformation and fake news (infodemic) thrive in the society

\section{CONCEPTUAL INVESTIGATIONS}

\section{Infodemic}

Infodemic has its etymology from information and epidemic (English Wiktionary). Infodemic refers to an excessive amount of information concerning a problem such that the solution to the problem is made more complex and difficult. Infodemic was first coined by World Health Organisation and the term refers to the dynamics of our modern information space, where trustworthy information is difficult to distinguish from an overwhelming din of competing, and in some cases conflicting, voices (Starbird, 2020). The term according to World Health Organisation (2019); Cinelli, Quattrociocchi, Galeazzi, Valensise, Brugnoli, Schmidt \& Scala (2020) has been coined to outline the dangers of misinformation trends during the management of virus outbreaks since it could even speed up the epidemic process by manipulating and fragmenting social response.
At a time of crisis or emergency, the information 'hunger' according to Adarsh \& Greeshma (2020) shoots up, with social media being the major feed. Therefore, Guterres (2020) says that "Our common enemy is \#COVID-19 but our enemy is also an "infodemic" of misinformation" (n.p). Information overload occurs when too much relevant information is arriving, particularly when it comes through the 'homogenising' lens of the web browser, which makes it difficult to distinguish which information is reliable and helpful from the harmful ones (Bawden \& Robinson, 2020). No doubt, infodemic can spread misinformation, disinformation, fake news and rumours during a health emergency such as the current era of COVID-19. It can thus lead people to feel overwhelmed and powerless and causes anxiety, fatigue, and paralysis of action; bad enough at any time, dangerous in a pandemic as currently being experienced. Hence, it can hamper an effective public health response and create confusion and distrust among people.

\section{Mis- and Disinformation}

The Merriam Websters Dictionary (2009) defines misinformation as incorrect or misleading information. It is also seen as false or inaccurate information especially that which is deliberately intended to deceive. For instance, when one tells something heard on television, radio or saw on newspaper and social media that was not really true but spread around the wrong information that unknowingly, then one is, technically, spreading misinformation.

Disinformation according to Merriam Websters Dictionary (2009) is false or misleading information deliberately and often covertly spread by the planting of rumours to influence public opinion or obscure the truth that is spread deliberately to deceive. In other words, disinformation is also used more generally to mean "deliberately misleading or biased information; manipulated narrative or facts; propaganda" (Dictionary.Com, n.d, n.p). Simply put then, disinformation is knowingly spreading misinformation. It can also be a subset of misinformation. This means that disinformation is false information that is given to people to make them believe something or to hide the truth. Looking at the definitions, of misinformation and disinformation, the main difference between the two is misinformation is shared accidentally, while disinformation is shared deliberately.

Although, the truth remains that mis- and disinformation about science, technology, and health is neither new nor unique to COVID-19. As the spread of COVID-19 continues to dominate global news sources, it is becoming clearer that a parallel pandemic of mis- and disinformation has also begun to erode public understanding of the crisis. As stated earlier, WHO has described the misinformation surrounding the COVID-19 pandemic as a "massive infodemic" and a major driver of the pandemic itself (West, 2020). Disinformation is enormously powerful, destructive, and divisive, and is a common tool of espionage (Dictionary.Com). In a like manner, the United Nations Educational, Scientific and Cultural Organisation (UNESCO) proposed that "the impacts 
of COVID-19 disinformation are more deadly than disinformation about other subjects, such as politics and democracy" (West, 2020, n.d).

Amid this unprecedented universal health crisis, many journalists, policymakers, and academics have continued to echo the position of WHO and stressed that misinformation about the pandemic presents a serious risk to public health and public action. In the case of COVID-19, information can be a literal lifesaver-when it is true but wrong information does not help anyone and can even make things worse. And like a virus, wrong information can spread, causing what is being called an infodemic (Dictionary.Com, n.d).

\section{Covid-19 Pandemic}

The global space, Nigeria inclusive has come to witness and experience a new coronavirus disease nicknamed COVID-19. This virus has a serious challenge with ripple effects on every aspect of human life - social, political, economic, education, technology, information, religion and the like. Similarly, Emefule Foundation (2020) affirms that the COVID-19 pandemic has significantly impacted the world, creating fear, instilling anxiety, catalysing economic downturns and drastic changes in people's social lives. This shows that the COVID-19 pandemic is redefining the totality of human life experiences. According to Cennimo (2020) Coronavirus disease, 2019 is defined as the illness caused by a novel coronavirus now called severe acute respiratory syndrome coronavirus 2 (SARS-CoV-2; formerly called 2019-nCoV), which was first identified amid an outbreak of respiratory illness cases in Wuhan City, Hubei Province, China (CDC. 2019).

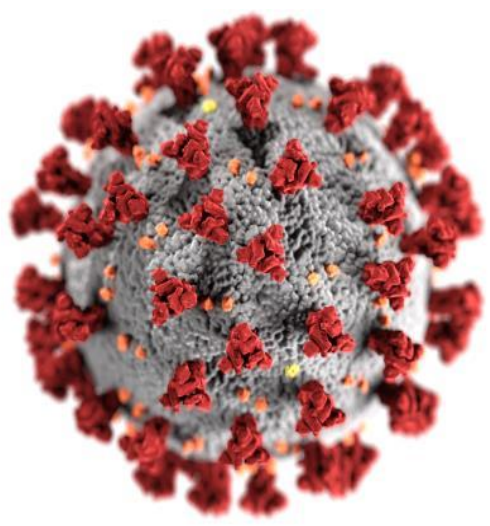

Fig. 1: Coronavirus disease (Source: CDC Online Newsroom)

It was initially reported to the WHO on December 31, 2019. On January 30, 2020, the WHO declared the COVID-19 outbreak a global health emergency (Gallegos, 2020; Ramzy, \& McNeil, 2020). According to The New York Times (2020) on March 11, 2020, the WHO declared COVID-19 a global pandemic, its first such designation since declaring H1N1 influenza a pandemic in 2009. The illness caused by SARSCoV-2 was recently termed COVID-19 by the WHO, the new acronym derived from "coronavirus disease 2019". The name was chosen to avoid stigmatizing the virus's origins in terms of populations, geography, or animal associations (The New York Times 2020; WHO Director-General, 2020). On February 11, 2020, the Coronavirus Study Group of the International Committee on Taxonomy of Viruses issued a statement announcing an official designation for the novel virus: severe acute respiratory syndrome coronavirus 2 (SARS-CoV-2) (Gorbalenya, 2020). As of $26^{\text {th }}$ June 2021, COVID-19 has affected about 222 countries globally and has infected over $181,397,000$ people and killed more than $3,929,000$ people with over 165 million people recovered from the novel virus worldwide (Worldometer, 2021).

In Nigeria, as in other countries in Africa and the world, the experience is not different. The COVID-19 pandemic in Nigeria is part of the worldwide pandemic of coronavirus disease 2019 caused by severe acute respiratory syndrome coronavirus 2 (SARS-CoV-2). The first index case was detected, confirmed and announced on 27th February 2020. It was an Italian citizen working in Nigeria. He was tested positive for the virus, caused by SARS-CoV-2. Equally, on 9th March 2020, a second case of the virus was reported in Ewekoro, Ogun State, a Nigerian citizen who had contact with the Italian citizen (Wikimedia, 2020). Currently, the virus has spread to all the 36 States in Nigeria and the Federal Territory inclusive. As of today $26^{\text {th }}$ June 2021 , as announced by the Nigeria Centre for Disease Control (NCDC), 167,430 people have been infected with the virus nationwide and 163,937 people recovered from the disease while 2,119 people died with the virus. Unfortunately, since these cases showed up in Nigeria, and as the cases continue to spread and increase daily, so also the rate at which false, disinformation and misinformation about many aspects of the virus spread like wildfire. Bawden \& Robinson (2020) say that the coronavirus pandemic has given rise to a relentless flood of information which leads people to pick out the bizarre and sensational. This is why the Emefule Foundation (2020) stresses that in Nigeria; the virus has begun to spread at a geometric rate, and with it, an infodemic signalled by a lack of adequate information, fake news and uneven distribution of news.

\section{Social Media Platforms as Drivers of Infodemic}

The global COVID-19 pandemic is happening at a time when differentiating facts from fiction is increasingly difficult particularly with the social media platforms serving as the hub for infodemics. Today, misinformation, disinformation cum fake news spread very easily courtesy of social media networks. Unfortunately, the number of people using different social media platforms keeps increasing per day. For instance, Facebook has some 2 billion subscribers and is followed by instant-messaging applications like WhatsApp, with some 1.5 billion users. It is further reported that Facebook users sent an average of 31.25 million messages and viewed 2.77 million videos every minute (Feris, 2017). That is an overabundance of information on just one social media site. Facebook and WhatsApp are the most accessed social media sites that complement the mainstream media landscape in Nigeria. 


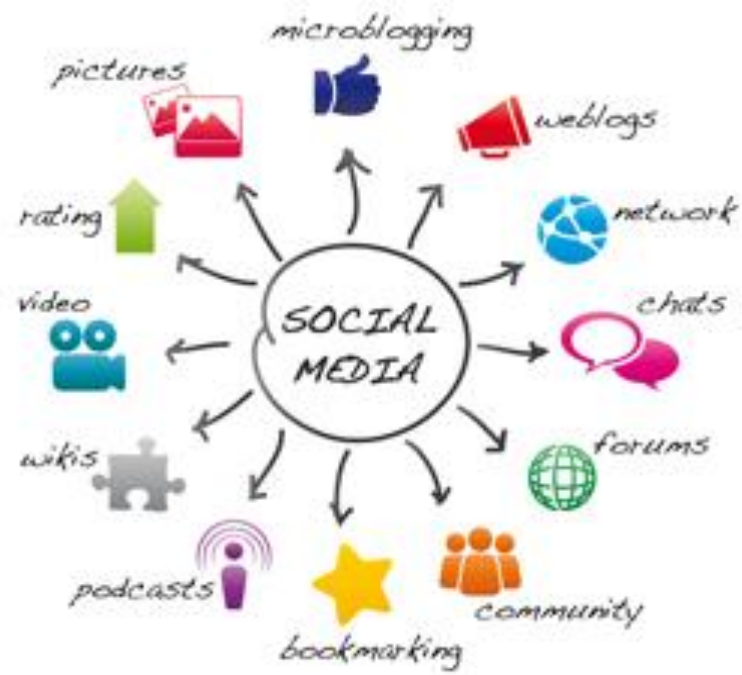

Fig. 2 Social Media Components

(Source: hvacrbusiness.com)

Although, Nigeria like other African countries has other favourable conditions, including press freedom, access to internet coverage and low-cost smartphones and laptop computers. Predictably, these advances would give rise to an information and exchange explosion, and the natural consequence is the increase of fake news, disinformation, misinformation and propaganda.

This is so, firstly because, on social media, users could share stories about the current COVID-19 without checking if those stories are true or not. Secondly, because of the severity of the coronavirus disease ravaging the whole world, with its daily spreading and killing people globally, it becomes a hot topic of discussion and interest on social media like Facebook, Twitter and Google.

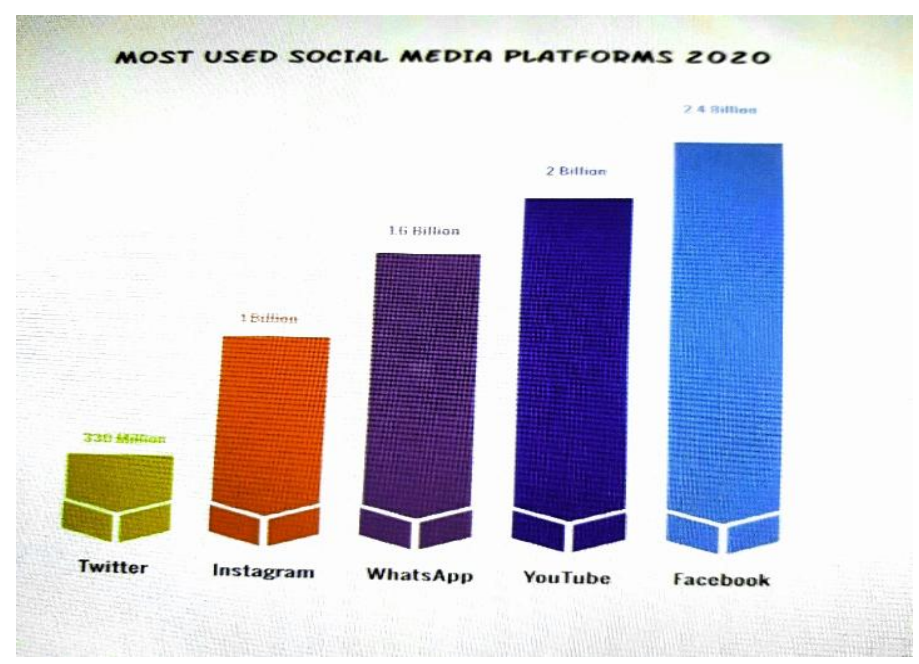

Fig. 4: Most used social media platforms during the COVID-19 Pandemic in 2020

(Source: Adarsh \& Greeshma, 2020)

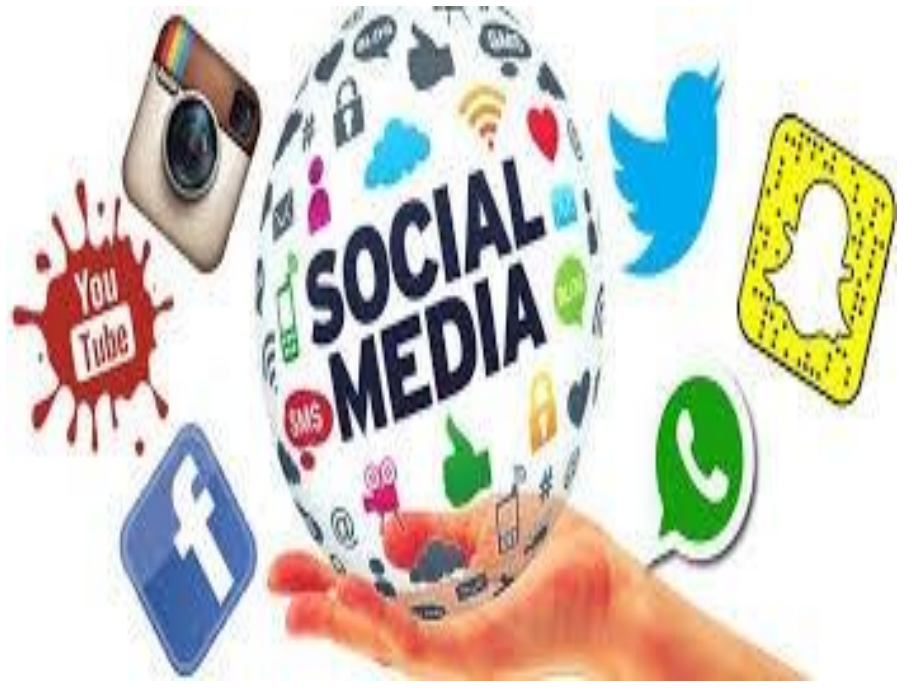

Fig. 3 Social Media Platforms

(Source: Quora)

In a way, social media is now a window into current events all across the world, and when everyone's attention is on one topic, it is understandable that consumers might reach 'information overload' (Amnesty International, 2020). Thus, social media platforms become potential drivers that provide direct access to an unprecedented quantity of content and increase misinformation, fake news, rumours and questionable information. Asserting this, Silverman (2016) argues that some fake news stories were more widely circulated on social media than the most popular real news stories (cited in JonesJang, Mortensen \& Liu, 2019).

Indeed, according to Bessi, Coletto, Davidescu, Scala, Caldarelli, and Quattrociocchi (2015), social media users tend to acquire information adhering to their worldviews and ignore dissenting information and form polarized groups around shared narratives. Unfortunately, when polarization is high, misinformation and fake news can easily proliferate (Vicario, Quattrociocchi, Scala, \& Zollo, 2019). Undeniably, these kinds of fake and inaccurate information spread more rapidly and wider than fact-based information.

Thus, Hassan (2020) affirms that the social media activists, influencers and self-styled warriors are using their social media platforms and fringe websites to proliferate misinformation, propagate conspiracy theories and promote the denial of COVID-19. He further claims that they do this to grow their online followership. A good example is a controversial blogger, Kemi Olunloyo, who tweeted on 24th March 2020 that President Muhammadu Buhari was sick with a persistent cough and that a makeshift ICU had been set up to treat him. Within hours, the tweet had been liked 3,300 times and retweeted more than 2,000 times (Hassan, 2020). Before this, on 23rd March 2020, an audio clip emerged on the WhatsApp platform of an alleged World Health Organization (WHO) official predicting that at least 45 million Nigerians 
would die in the pandemic. Of course, this audio clip exasperated so much attention that the National Centre for Disease Control (NCDC) issued a rebuttal immediately.

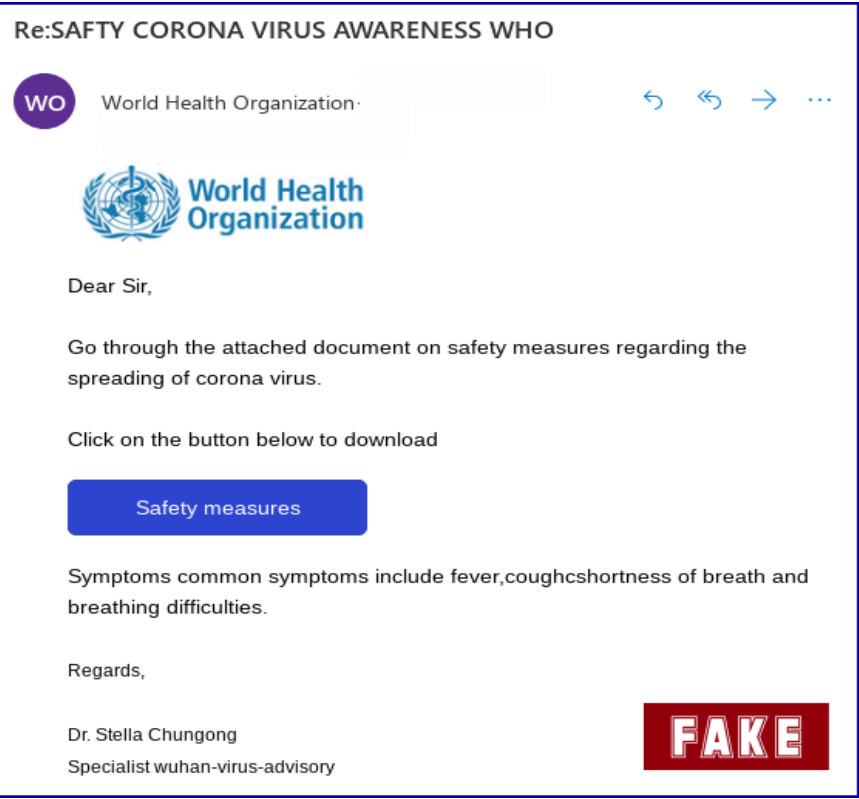

Fig. 5: Email impersonating WHO. (Adarsh \& Greeshma, 2020).

Another mis- and disinformation that circulated was in a tweet which claimed that "the drug Chloroquine Phosphate is the number one cure for COVID-19". Another tweet that also garnered hundreds of retweets according to Shayiq (2020) was that "so Chloroquine Phosphate has proven to be very effective in treating the coronavirus \#COVID19 and has shown positive clinical results" (n.p). This 'magic cure' for coronavirus has also been widely shared on Whatsapp in Nigeria. Equally, on social media platforms is the false claim that went viral that the virus can be cured with constant sex or sitting in the sun. Furthermore, there is also a claim that African blood is immune to the coronavirus. Unfortunately, none of these has any medical basis and many Nigerian citizens did not boarder to fact-check these claims before accepting, sharing and using them. Thus, as we are battling with the virus pandemic, many people are dying of information pandemic.

\section{Infodemic and its Impact on Society}

Hassan (2020), states that the fear of the unknown and a deluge of information in the digital space creates fertile ground for fake news and infodemic to triumph. Nigerians may be particularly vulnerable not because they are uniquely gullible, but because of weak communications between the government and the governed, high reverence for miracle healing and a dilapidated health care system. But most importantly, most Nigerians are media and information illiterates and thereby, lack the ability and capability to factcheck information they receive.

Moreover, the threat of infodemic is even greater in 2020 than in the 2014 Ebola epidemic. For instance, in 2015, Nigeria had 76 million internet subscribers and by 2019, this had increased to 122 million (Hassan, 2020). With the reality of COVID-19, false information is more sophisticated than ever and its potential spread much wider since the pandemic cut across the entire globe. This increment suggests that Nigeria does not just have to combat the COVID-19 pandemic but also the infodemic. A review by the Centre for Democracy and Development since the virus reached Nigeria suggests that purveyors of fake news have sought to incite panic, panic buying, proffer fake cures, undermine medical advice, promote hate speech particularly individuals of Nigerian origin (Hassan, 2020). Similarly, Suraj (2020) argues that infodemics can breed mistrust, fuel conflicts and engender hatred in the country.

Indeed, mis- and disinformation is unethical, dangerous, provocative, and subversive to peace of individuals and societal serenity especially in a period of a pandemic in a multicultural setting like Nigeria as it heightens the tension and builds fear and mistrust among people (Abdullahi, 2017). In other words, infodemic in a time of pandemic and uncertainty could "threaten and destroy" the unity and peace of the country. Pate (2018) outlines some critical repercussions of infodemics in the society to include the following: (a) infodemic can undermine the unity and peace of the country with explosive consequences; (b) by its nature, democracy looks adversarial, but fake news makes it worse; (c) it exacerbate distrust, division and violence in the already divided diverse polity; (d) it can undermine confidence and certainty of the citizens in the media particularly the social media; and (e) infodemic can promote anti-democratic tendencies that can subvert confidence in the system.

From the foregoing, fake news, mis- and disinformation are a real challenge in Nigeria especially given the country's fragile social setting, loose democratic culture, poverty, illiteracy, depressing human conditions, inflation, a weak economy, intolerance and high tendencies for disunity among the peoples of the country (Ogola, 2017 cited in Pate, Gambo, Ibrahim, 2019). Without clear and immediate action to tackle infodemics, the accompanying pandemic of mis- and disinformation would continue to make the COVID-19 pandemic much more challenging. This means that as people are being informed and sensitised to protect themselves from the pandemic, there is also an urgent need for people to be empowered against infodemics. 

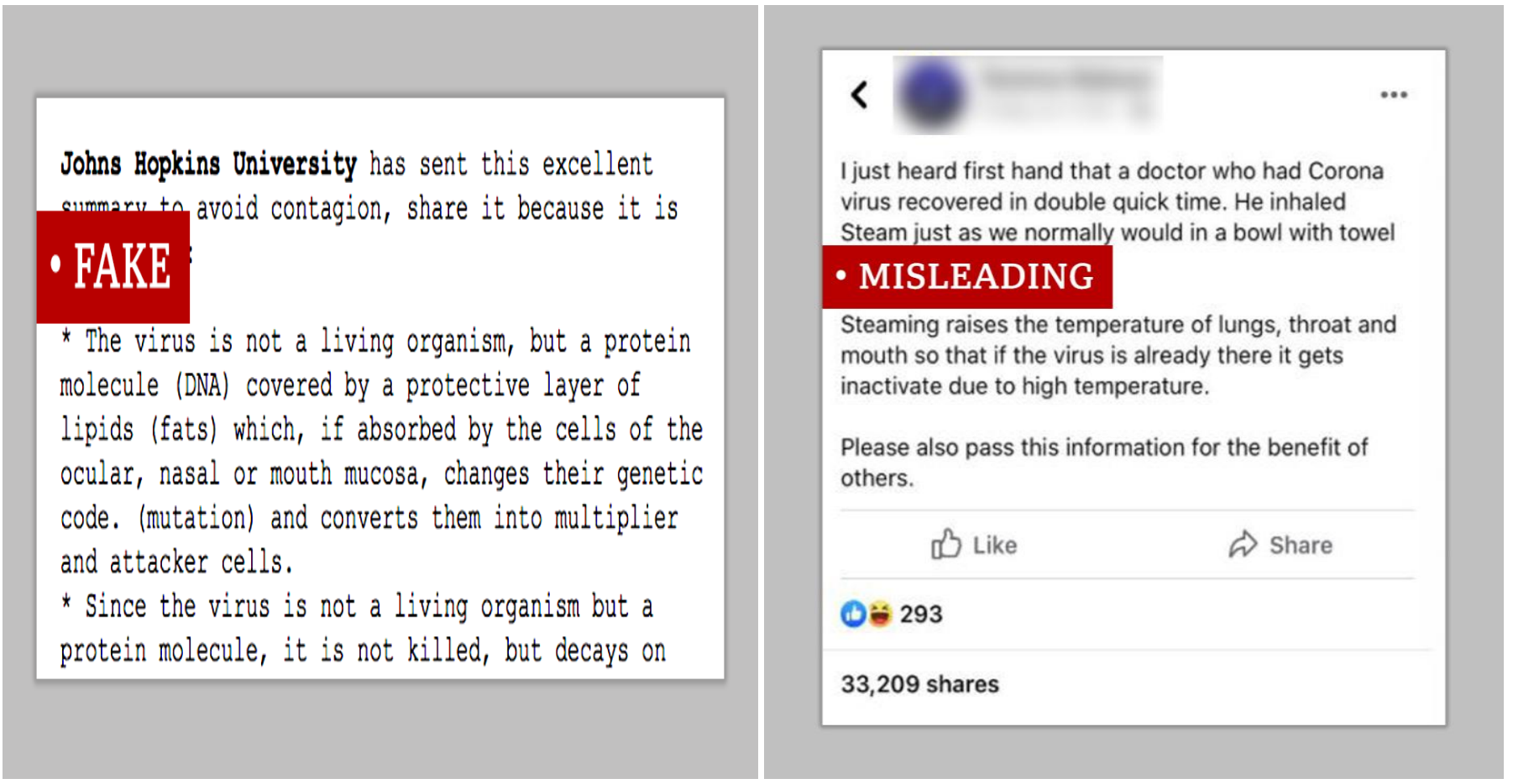

Fig. 6 Fake and Misleading information/stories of COVID-19 that went viral (Source: BBC.com)

Thus, as Nigeria rises to curtail the negative impact of infodemics on her citizens, particularly in pandemic times, Pate (2018) proposes media literacy as a means to increase the standard of education and media and information literacy, particularly of young people. This will make them overly critical of the information they receive from both conventional and social media platforms. In the same vein, The Global UNESCO-led MIL Alliance (GAPMIL) states that to stop the spread of misinformation, control the information fog, and better focus on developing healthy media and information environments for all, media and information literacy is vital for all citizens. It is believed that by having the ability to critically manage and engage with information particularly in times of crises, MIL can help people to progress towards positive values such as solidarity, generosity and togetherness. In other words, for individuals to be better able to curtail infodemics in Nigeria, MIL becomes a necessity.

\section{What is Media and Information Literacy (MIL)?}

Information literacy and media literacy are conventionally seen as separate and distinct fields. However, UNESCO's strategically brings them together as a combined set of competencies (knowledge, skills and attitude) necessary for life and work in the era of digital technology proliferation. Hence, the combined media and information literacy form a set of skills, without which a $21^{\text {st }}$-century citizen finds it hard to understand the surrounding world (Feris, 2017). The most cited definition is Aufderheide's (1993) which sees it as the "ability of a citizen to access, analyze, and produce information for specific outcomes" (p. 6). Congruently, UNESCO (2017) asserts that MIL considers all forms of media and other information providers such as libraries, archives, museums and the Internet irrespective of the technologies used. However, UNESCO (2013) defines MIL as the skills and competencies that empower citizens to access, retrieve, use, understand, evaluate, create, as well as share information and media content in all formats using various tools in a critical, ethical and effective ways, in order to participate and engage in personal, professional and societal activities.

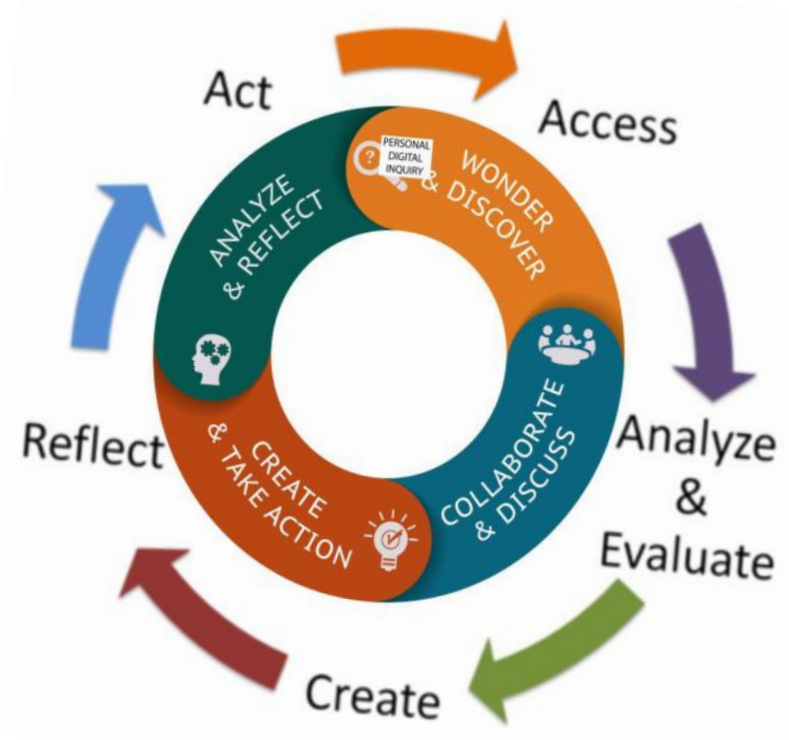

Fig. 7 Process of media literacy (Source Renee Hobbs Twitter, 2017) 
The fundamental assumptions of MIL include the principles that: media are constructed and construct reality; media have commercial, ideological, and political motivations and implications; form and content are related; each medium has unique aesthetics and conventions, and, finally, receivers negotiate the meanings of messages (Aufderheide, 1993). Thus, the essence of educating people in these principles is to create informed, autonomous citizens who would be able to question the information they receive, appreciate aesthetics, develop self-esteem and competence, and have a sense of advocacy (Aufderheide, 1993; Tyner, 1998).

The truth remains that MIL promotes individuals' rights to communicate and express and to seek, receive and impart information and ideas. It encourages the evaluation of media and other information providers based on how they are produced, the messages being conveyed, and the role of the intended audience. This is the reason UNESCO (2017) stresses that MIL is an important prerequisite for fostering equitable access to information and knowledge and promoting free, independent and pluralistic media and information systems. Corroborating this view, Feris (2017) says that the skilful application of literacy to media and information is a must for media users. Therefore, MIL is a set of core competencies (knowledge, skills and attitudes) that is required for everyday life.

No doubt, MIL provides a conceptual framework and methodology to develop awareness, access, analyze, critically evaluate, and produce media in their various forms. This encompasses three main dimensions:

1. Critical - developing the critical competence to analyze and assess the media as cultural, social and economic institutions;

2. Creative - developing and enhancing creativity to enable the use of the media for expression, interpersonal communication and active participation in the public arena;

3. Cultural - broadening knowledge and experience of different kinds of media forms, content, and technology.

Based on these concepts, it is believed that MIL:

1. Empowers people to interact and engage critically with media in local and global socio-political, economic and cultural contexts;

2. Enables people, through the use of the media, to become active citizens able to exercise their democratic rights and responsibilities;

3. Engages people to analyze media messages concerning their institutions, codes and conventions, audiences, technologies and ideologies;

4. Provides ways for people to make informed choices;

5. Inspires the creative and democratic use of the media to express and communicate ideas, information and opinions, as well as to entertain and promote participation in the creation of content;

6. Encourages the use of information and communication technologies (ICTs) to shape and share alternative content, media products and services to meet the individual, community, and regional needs and interests;

7. Promotes interpersonal communication to build positive relationships, family life, and community;

8. Enhances the dignity of the human person and the potential for ethical/moral and spiritual development, in solidarity with the poor, and with respect for the earth and cultural heritages.

From the foregoing, therefore, MIL certainly recognizes the primary role of information and media in people's everyday lives. It lies at the core of freedom of expression and information - since it empowers citizens to understand the functions of media and other information providers, to critically evaluate their content, and to make informed decisions as users and producers of information and media content (UNESCO, 2017). One can say that the basic skills of MIL include asking specific questions and backing up one's opinions with verifiable examples. Thus, following the above MIL concepts and skills, it allows people to learn for themselves what a given piece of media content is all about, why it was made, and what they want to think about it. In other words, MIL empowers individuals to make informed choices and decisions concerning media products.

\section{MIL as a Tool of Curbing Infodemic in a Pandemic Context}

Common Sense Media (n.d) makes it clear that the digital age has made it easy for anyone to create and share media content. Thus, there is a need to know who creates media content, why it is created and its credibility. This makes media and information literacy a necessity in curbing or reducing the rate of the spread of fake news, mis- and disinformation among the people particularly the younger generation. Pate (2018) points out that if individuals are media and information literate, they will be able to instantaneously recognize and avoid swimming in the ocean of infodemics. They will be equipped with the skills to (1) Check sources: individuals are encouraged to fall back on the most trusted news brands they could rely on for their news. (2) Fact-check from multiple sources (3) Use verification tools (4) Check metadata (5) Think before broadcasting/publishing (6) Use fact-checking sites (7) Individuals would cultivate the culture of fact-checking for stories and claims.

Through MIL skills, citizens would be able to evaluate media and social media messages by asking these simple questions:

- Who is sending the message? Was it a company? Was it a blogger? Was it an individual? (If so, who?) Was it a comedian? Was it an artist? Was it an anonymous source? 
- Why did they make it? Was it to inform you of something that happened in the world (for example, a news story)? Was it to change your mind or behaviour (an opinion essay or a how-to)? Was it to make you laugh (a funny meme)? Was it to get you to buy something (an ad)?

- What techniques are used to attract my attention? Does it have statistics from a reputable source? Does it contain quotes from a subject expert? Does it have an authoritative-sounding voice-over? Is there direct evidence of the assertions it is making?

- How might different people interpret the message differently than I do? Do you think others might feel the same way? Would everyone feel or interpret the same, or would certain people disagree with my interpretation?

- What lifestyles, values or points of view are represented or omitted from the message? Whose view is the message representing? Is the information balanced with different views -- or does it present only one side? Do you need more information to fully understand the message?

- Why is the message being sent? Is it for kids? Grown-ups? Girls? Boys? People, who share a particular interest?

Concurrently, according to Common Sense Media (n.d), media and information literacy is an essential skill in the digital age because of its accumulated abilities to help people:

Learn to think critically: As they evaluate social media content, they would be able to decide whether the messages make sense, why certain information was included, what was not included, and what the key ideas are. They would also learn to use examples to support their opinions. In this way, they can make up their minds about the information they receive based on the knowledge they already have.

Become a smart consumer of products and information: MIL helps people learn how to determine whether media content is credible or not. It also helps them determine the "persuasive intent" of advertising and resist the language and techniques advertisers, bloggers; marketers use to project and sell their products.

Recognise the point of view: Every creator has a perspective. With MIL, people would be equipped with the ability to identifying an author's point of view which would help to appreciate different perspectives. It would also help them to put information in the context of what they already know -- or think they know.

Understand the author's goal: MIL equips people with the skill of enquiry. They would be able to ask questions such as: what does the author want you to take away from a piece of media? Is it purely informative, is it trying to change your mind, or is it introducing you to new ideas you have never heard of? When people understand what type of influence the media content has on them, they can make informed choices and decisions.

Create media responsibly: MIL enables young people to recognise their own points of view by telling their own stories themselves. They would be able to say what they want to say in an appropriate way they want to say it and also understanding that the impact of their messages is key to effective communication.

\section{III.CONCLUSION}

From the foregoing, the position of the present article suggests that infodemics vis a vis fake news, disinformation and misinformation about COVID-19 could come in many different forms, from various sources on social media platforms, and makes many different claims in order to cause fear, panic, disunity among the people and in most cases to build followers or likes. News about Coronavirus disease is frequently reconfigured and manipulates the existing or true content by individual social media users and bloggers with simple tools. Thus, the recent upheaval of infodemics, particularly about the Coronavirus disease has invited attention greater than ever before to the notion of media and information literacy. There is an urgent need in Nigeria and beyond to counter the scourge of fake news around coronavirus. As we have seen around the world, tackling the disease requires everyone to follow the advice and do their part. Accurate information is critical.

At this critical moment in our history and time, MIL is more needed than ever to educate citizens particularly the young people who are technologically driven to be conscious and careful of the information they receive and share through critical thinking and enquiry process. This would be in line with UNESCO's mission to engender media and information literate societies through a comprehensive strategy of the provision of set skills of media and information for people. Thus, the media and information literacy approach, which is the main focus of this article, calls for the citizens' critical ability to process media contents and information. It is believed that if the MIL skills are properly imbibed and practised, Nigerian citizens would be better equipped with the cognitive ability to discern facts from fake stories. The key assertion of this approach is that users with greater literacy on media and information are better able to recognize and refute fake news, mis- and disinformation online.

\section{IV.RECOMMENDATION}

Based on the position of this article, and to rapidly and effectively counter and curb disinformation and misinformation, the following are recommended:

1. MIL should be integrated into the curricula of schools at all levels in Nigeria.

2. The Nigeria government must engage in sustained two-way communication with its citizens. 
3. School authorities should train teachers on media issues to be able to sensitize the learners on the importance of MIL in the education process,

4. School authorities and policymakers should provide appropriate pedagogical methods, curricula and resources for teachers

5. Students and young people should always critically evaluate and synthesise information they receive before accepting and sharing them with others.

\section{REFERENCES}

[1] Abdullahi, B. (2017). Democracy and the challenge of fake news. The Cable. Retrieved from https://www.thecable.ng/democracychallenge-fake-news

[2] Adarsh, N. \& Greeshma, M.R. (2020). The infodemic: Infomania, social engineering and the pandemic - break the chain. Imprint: Independently Published.

[3] Aduloju, E.T. (2019). E-connectivity of the disconnected humanity in a digital world: The African perspective. In J.P. Egunjobi (ed.). The biopsychosocio-spiritual communication. Morrisville: Lulu Press Inc. Pp. 80-106.

[4] Amnesty International, (2020). How to deal with news overload during the covid-19 crisis. https://www.amnesty.org/en/latest/campaigns/2020/04/how-todeal-with-news-overload-during-the-covid-19-crisis/

[5] Aufderheide, P. (1993). Media literacy. A report of the National Leadership Conference on Media Literacy. Washington, DC: Aspen Institute, Communications and Society Program.

[6] Bawden, D. \& Robinson, L. (2020). COVID-19 information overload leads to simple but unhelpful choices. Retrieved from https://www.eurekalert.org/pub_releases/2020-04/culcio040120.php.

[7] Bessi, A., Coletto, M., Davidescu, G.A. Scala, A., Caldarelli, G. \& Quattrociocchi, W. (2015). Science vs con-spiracy: Collective narratives in the age of misinformation. PloS one, $10(2: \mathrm{e} 0118093$.

[8] CDC, (2019). Novel Coronavirus, Wuhan, China. CDC. Retrieved from ncov/about/index.html.

[9] Cennimo, D. J. (2020 Coronavirus Disease 2019 (COVID-19). Retrieved from. https://emedicine.medscape.com/article/2500114overview.

[10] Cinelli, M., Quattrociocchi, W., Galeazzi, A., \& Jasus, L. (2006) Guidelines on Information literacy for lifelong learning. IFLA. Retrieved from http://www.ifla.org/files/assets/informationliteracy/publications/ifla-guidelines-en.pdf.

[11] Cinelli, M., Quattrociocchi, W., Galeazzi, A., Valensise, C.M., Brugnoli, E., Schmidt, A.L., \& Scala, A. (2020). Thecovid-19 social media infodemic. arXiv preprint arXiv: 2003.05004.

[12] Common Sense Media (n.d). News and media literacy. Retrieved from https://www.commonsensemedia.org/news-and-medialiteracy/what-is-media-literacy-and-why-is-it-important.

[13] Emefule, T. Foundation (2020). Olasupo Abideen launches media initiative to battle fake news. Retrieved from https://www.tonyelumelufoundation.org/making-impact-duringcovid-19-pandemic/how-olasupo-abideen-is-battling-fake-newsduring-covid-19.

[14] English Wiktionary (n.d). infodemic. Retrieved from https://en.wiktionary.org/wiki/infodemic.

[15] Feris, L. (2017). YALI Voices: Media and information literacy for a better future! Retrieved from https://yali.state.gov/yali-voices-media-and-information-literacyfor-a-better-future/.

[16] Gallegos A. WHO Declares Public Health Emergency for Novel Coronavirus. Medscape Medical News. Retrieved from https://www.medscape.com/viewarticle/924596.

[17] Gorbalenya, A.E. (2020). Severe acute respiratory syndromerelated coronavirus - The species and its viruses, a statement of the Coronavirus Study Group. Retrieved from https://doi.org/10.1101/2020.02.07.937862.

[18] Guterrres, A. (2020). Misinformation about COVID-19 is a new enemy. Retrieved from

[19] Haris, A. R. Issues in digital era. Retrieved from https://www.researchgate.net/publication/328528038_Issues_In_D igital_Era

[20] Jones-Jang, S.M., Mortensen, T. \& Jingjing, L. (2019). Does media literacy help identification of fake news? Information literacy helps, but other literacies don't. American Behavioral Scientist. Sage Publications pp.1-18.

[21] Lau, L. J. (2003). Economic growth in the digital era. Retrieved from

http://web.stanford.edu/ 1jlau/Presentations/Presentations/031129. pdf

[22] Merriam-Webster.com Dictionary, (2019). Disinformation. Retrieved from https://www.merriamwebster.com/dictionary/disinformation.

[23] Nigeria Centre for Disease Control (2021). Covid-19 Nigeria: Confirmed cases by state. Retrieved from https://covid19.ncdc.gov.ng/

[24] Ogola, G. (2017). Africa has a long history of fake news after years of living with non-truth. The Conversation. Retrieved from https://theconversation-

com.cdn.ampproject.org/v/s/theconversation.com/amp/africa-hasa-long-history-of-fake-ne ws-after-years-of-living-in-non-truth73332

[25] Pate, U. A. (2018). Fake news, hate speech and Nigeria's democratic sustenance. PowerPoint slides of a presentation at a colloquium to mark the Press Week of the Nigerian Union of Journalists, Plateau State Chapter, Jos, pp. 6-10.

[26] Pate, U.A., Gambo, D. \& Ibrahim, A.M. (2019). The impact of fake news and the emerging post-truth political era on Nigerian polity: A review of literature. Studies in Media and Communication, 7(1), 21-29.

[27] Ramzy A, M. (202. 0)W.H.O. declares global emergency as Wuhan Coronavirus spreads. The New York Times. Retrieved from https://nyti.ms/2RER70M.

[28] Shayiq, A. (2020). Efficacy of chloroquine in treatment of COVID-19 is still underway. Retrieved from https://www.haasia.com/efficacy-of-chloroquine-in-treatment-of-covid-19-is-stillunderway/

[29] Starbird, K. (2020). How to cope with an infodemic Retrieve from https://www.brookings.edu/techstream/how-to-cope-with-aninfodemic/

[30] Suraj, O. (2020). Flattening the curve of mis(dis)information and mis(dis)trust through media and information literacy in the era of Covid-19 pandemic and infodemic. Retrieved from https://authorityngr.com/2020/04/14/flattening-the-curve-ofmisdisinformation-and-misdistrust-through-media-andinformation-literacy-in-the-era-of-covid-19-pandemic-andinfodemic/

[31] The New York Times, (2020). Coronavirus updates: The illness now has a name: COVID-19. Retrieved from https://www.nytimes.com/2020/02/11/world/asia/coronaviruschina.html.

[32] The New York Times (2020). Coronavirus live updates: W.H.O. declares pandemic as number of infected countries grows. Retrieved https://www.nytimes.com/2020/03/11/world/coronavirusnews.html\#link-682e5b06.

[33] Tyner, K. (1998). Literacy in a digital world. Mahwah, NJ: Lawrence Erlbaum.

[34] UNECSO, (2017). Media and information literacy. Retrieved from http://www.unesco.org/new/en/communication-andinformation/media-development/media-literacy/mil-as-compositeconcept/\#.

[35] UNESCO, (2013). Global media information and literacy: Assessment framework, country readiness and competencies. Paris, France: United Nations Educational, Scientific and Cultural Organization (UNESCO). 
[36] Vicario, M.D., Quattrociocchi, W., Scala, A. \& Zollo, F. (2019). Polarization and fake news: Early warning of potential misinforma-tion targets. ACM Transactions on the Web (TWEB), $13(2), 1-22$.

[37] West, J. (2020). Disinfodemic: Sources and targets of COVID-19 disinformation. Retrieved from https://www.hsdl.org/c/disinfodemic-sources-andtargets-of-covid-19-

disinformation/?utm_source=rss\&utm_medium=rss\&utm_campai $\mathrm{gn}=$ disinfodemic-sources-and-targets-of-covid-19-disinformation .

[38] Wikimedia (2020). COVID-19 pandemic in Nigeria. Retrieved from https://en.wikipedia.org/wiki/COVID19_pandemic_in_Nigeria.

[39] World Health Organisation (2019). Novel coronavirus (2019$\mathrm{nCoV})$ situation report-13. Retrieved from https://www.who.int/docs/default-sourse/coronaviruse/situationrepoerts/20200202-sitrep-13-ncov-v3.pdf?sfvrsn=195f40106.

[40] World Health Organisation (2020). Director-General's remarks at the media briefing on 2019-nCoV on 11 February 2020. Retrieved from https://www.who.int/dg/speeches/detail/who-directorgeneral-s-remarks-at-the-media-briefing-on-2019-ncov-on-11february-2020.

[41] Worldometer (2020). COVID-19 Coronoanvirus pandemic update (Live). Retrieved from https://www.worldmeters.info.

[42] Worldometer (2021). COVID-19 Coronoanvirus pandemic update (Live). Retrieved from https://www.worldmeters.info.

[43] Zarocostas, J. (2020). How to fight infodemic. Published online by Elsevier Public Health Emergency Collection on February 27, $2020 . \quad$ Retrieved https://www.ncbi.nlm.nih.gov/pmc/articles/PMC7133615/. 